Research report

\title{
Lipopolysaccharide induced increase in seizure activity in two animal models of absence epilepsy WAG/Rij and GAERS rats and Long Evans
}

\section{rats}

\author{
Zsolt Kovács $^{\mathrm{a}, *}$, Árpád Dobolyi ${ }^{\mathrm{b}, \mathrm{c}, 1}$, Gábor Juhász ${ }^{\mathrm{d}, 2}$, Katalin A. Kékesi ${ }^{\mathrm{d}, \mathrm{e}, 2}$ \\ a Department of Zoology, University of West Hungary Savaria Campus, Károlyi Gáspár tér 4, 9700 Szombathely, Hungary \\ ${ }^{\mathrm{b}}$ Laboratory of Molecular and Systems Neurobiology, Institute of Biology, Hungarian Academy of Sciences and Eötvös Loránd University, Pázmány Péter \\ sétány 1C, 1117 Budapest, Hungary \\ ${ }^{c}$ Laboratory of Neuromorphology, Department of Anatomy, Histology and Embryology, Semmelweis University, Tüzoltó u. 58, 1094 Budapest, Hungary \\ d Laboratory of Proteomics, Eötvös Loránd University, Pázmány Péter sétány 1C, 1117 Budapest, Hungary \\ e Department of Physiology and Neurobiology, Eötvös Loránd University, Pázmány Péter sétány 1C, 1117 Budapest, Hungary
}

\section{A R T I C L E I N F O}

\section{Article history:}

Received 25 January 2014

Received in revised form 20 March 2014

Accepted 24 March 2014

Available online 1 April 2014

\section{Keywords:}

Lipopolysaccharide

Indomethacin

Spike-wave discharges

Absence epileptic rats

\begin{abstract}
A B S T R A C T
We showed previously that the number and time of spike-wave discharges (SWDs) were increased after intraperitoneal (i.p.) injection of lipopolysaccharide (LPS), an effect, which was completely abolished by cyclooxygenase-2 (COX-2) inhibitor indomethacin (IND) pretreatment in Wistar Albino Glaxo/Rijswijk (WAG/Rij) rats. These and other results suggest that injection of LPS to genetically absence epileptic animals, such as WAG/Rij rats, may allow us to investigate relationships between absence epilepsy and LPS evoked neuroinflammation processes. However, LPS may evoke different effects on absence epileptic activity in various animal strains. Thus, to extend our previous results, we injected two doses of LPS $(50 \mu \mathrm{g} / \mathrm{kg}$ and $350 \mu \mathrm{g} / \mathrm{kg}$ i.p.) alone and in combination with IND $(10 \mathrm{mg} / \mathrm{kg}$ IND i.p. $+50 \mu \mathrm{g} / \mathrm{kg}$ LPS $)$ into rats of two model animal strains (WAG/Rij rats; GAERS rats: Genetic Absence Epileptic Rats from Strasbourg) and into Long Evans rats. The effects of treatments on SWD number and SWD duration were examined. Both doses of LPS increased the SWD number and the total time of SWDs dose-dependently during the whole 4 -h recording period, which was abolished by IND pretreatment in all three investigated strains. These results extend our previous results suggesting that our methods using LPS injection into freely moving absence epileptic rats is applicable not only in well-established animal models of absence epilepsy such as WAG/Rij rats and GAERS rats but also in Long Evans rats to investigate links between inflammation and absence epilepsy.
\end{abstract}

(c) 2014 Elsevier Inc. All rights reserved.
Abbreviations: AMPA receptor, alpha-amino-3-hydroxy-5-methyl-4isoazolepropionic acid receptor; CNS, central nervous system; COX-2, cyclooxygenase-2; EEG, electroencephalogram; GAERS rats, Genetic Absence Epileptic Rats from Strasbourg; HVRS, high-voltage rhythmic spike; IL-1 $\beta$, interleukin-1 $\beta$; IL-1R, interleukin-1 receptor; IND, indomethacin; i.p., intraperitoneal; LPS, lipopolysaccharide; $\mathrm{PGE}_{2}$, prostaglandin $\mathrm{E}_{2}$; PTC day, post-treatment control day; SWD, spike-wave discharge; TLR4, Toll-like receptor 4; TNF- $\alpha$, tumor necrosis factor- $\alpha$; WAG/Rij rats, Wistar Albino Glaxo/Rijswijk rats.

* Corresponding author at: Department of Zoology, University of West Hungary, Savaria Campus, Szombathely, Károlyi Gáspár tér 4, 9700, Hungary. Tel.: +36 94504 409; fax: +3694504 404 .

E-mail addresses: zskovacs@ttk.nyme.hu (Z. Kovács), dobolyi@med.semmelweis-univ.hu (Á. Dobolyi),gjuhasz@dec001.geobio.elte.hu (G. Juhász), kakekesi@dec001.geobio.elte.hu (K.A. Kékesi).

1 Tel.: +361215 6920; fax: +3612181612.

2 Tel.: +361372 2500; fax: +3613812204

\section{Introduction}

It has been shown that enhanced pro-inflammatory cytokine levels can increase the susceptibility to epileptic seizure (Galic et al., 2008; Vezzani et al., 2008). Indeed, pro-inflammatory cytokines (e.g., interleukin-1 $\beta$ (IL-1 $\beta$ ) and tumor necrosis factor- $\alpha$ (TNF$\alpha)$ ) synthesized by glial cells in the central nervous system (CNS) elevate neuronal excitability (Rodgers et al., 2009; Vezzani et al., 2008; Vezzani and Granata, 2005). Changes in IL-1 $\beta$ and TNF- $\alpha$ levels may have a role in SWD generation/precipitation in two animal models of human absence epilepsy, GAERS rats and WAG/Rij rats (Akin et al., 2011; Van Luijtelaar et al., 2012). Lipopolysaccharide evokes rapid excitation in the cortex (Wang and White, 1999), enhances seizure susceptibility (Sayyah et al., 2003), increases absence epileptic activity and body temperature (Kovács et al., 2006, 2011) and changes protein expression in the WAG/Rij rat 
brain (Györffy et al., 2014). These effects of LPS may be mediated by increased levels of pro-inflammatory cytokines and interleukin-1 receptor/Toll-like receptor (IL-1R/TLR) signaling in the CNS (Turrin et al., 2001; Vezzani et al., 2011).

Lipopolysaccharide, a cell wall component of gram-negative bacteria, belongs to the pathogen-associated molecular patterns (PAMPs) (Vezzani et al., 2011), which induce rapid synthesis of other cytokines and COX-2 via Toll-like receptor 4 (TLR4) evoked induction of transcriptional factors (e.g., nuclear factor $\kappa \mathrm{B}, \mathrm{NF \kappa B}$ ) in the CNS (Vezzani and Granata, 2005). Systemic injection of LPS to rats is a well-studied and described way for precipitation of inflammatory reactions in the CNS (Vezzani and Granata, 2005), which is also suitable for investigation of links between immune system and absence epileptic activity (Kovács et al., 2006). Lipopolysaccharide injected into genetically absence epileptic animals such as WAG/Rij rats, the animal strain, which is one of the most appropriate animal model strains for the study of spontaneous childhood absence epilepsy (Depaulis and Van Luijtelaar, 2005), could provide an opportunity for the investigation of the relationships between non-convulsive types of epilepsies such as absence epilepsy and LPS/cytokine evoked neuroinflammatory processes (Kovács et al., 2006), which is still incompletely understood. We previously demonstrated that i.p. application of LPS dose-dependently increased the absence epileptic activity in freely moving WAG/Rij rats (Kovács et al., 2006). Other absence epileptic animals may also be promising models to investigate the links between inflammation and epilepsy. However, the effects of LPS on absence epileptic activity in freely moving animals have not been investigated in genetically epileptic GAERS rats and Long Evans rats. It was recently demonstrated that Long Evans rats also produce SWDs similarly to WAG/Rij rats and GAERS rats (Depaulis and Van Luijtelaar, 2005; Huang et al., 2012; Polack and Charpier, 2006; Shaw, 2004, 2007; Shaw et al., 2009; Van Luijtelaar et al., 2011) allowing the investigation of SWDs in this strain as well. Therefore, to validate and extend our previous results, in which we demonstrated the LPS induced increase in absence epileptic seizures in WAG/Rij rats (Kovács et al., 2006) we injected two doses of LPS ( $50 \mu \mathrm{g} / \mathrm{kg}$ and $350 \mu \mathrm{g} / \mathrm{kg}$ i.p.) alone, and $50 \mu \mathrm{g} / \mathrm{kg}$ LPS in combination with $10 \mathrm{mg} / \mathrm{kg}$ IND into WAG/Rij rats, GAERS rats and Long Evans rats to investigate the effects of treatments on absence epileptic activity by detecting and evaluating SWDs.

\section{Materials and methods}

\subsection{Animals}

Eight months old male WAG/Rij rats, GAERS rats and Long Evans rats (housed at the Department of Zoology, University of West Hungary, Savaria Campus, Szombathely, Hungary) were used in the experiments. Animals were kept in groups of 3-4 under standard laboratory conditions (12:12 h light-dark cycle, light was on from 08.00 AM to 08.00 PM), with free access to food pellets and water. Rats were maintained in air-conditioned rooms at $22 \pm 2{ }^{\circ} \mathrm{C}$ and were housed individually after surgery and during the experiments.

Animal treatment and surgery procedures were carried out according to the local ethical rules in accordance with the Hungarian Act of Animal Care and Experimentation (1998, XXVIII, section 243/1998) in conformity with the regulations for animal experimentation in the European Communities Council Directive of 24 November 1986 (86/609/EEC). All efforts were made to reduce the number of animals used and to minimize pain and suffering.

\subsection{Recording of absence epileptic activity and body temperature}

\subsubsection{Implantation of animals for EEG recording and body temperature measuring}

Wistar Albino Glaxo/Rijswijk rats $(n=20)$, GAERS rats $(n=20)$ and Long Evans rats $(n=20)$ were anaesthetized by halothane-air mixture $(0.8-1 \%)$ and implanted with screw electrodes as described earlier (Kovács et al., 2006). Briefly, stainless steel screw electrodes were placed into the bone above the frontal (AP: $2.0 \mathrm{~mm}$; $\mathrm{L}$ : $2.1 \mathrm{~mm}$ ) and parietal (AP: $-6.5 \mathrm{~mm}$; L: $2.1 \mathrm{~mm}$ ) cortices (Paxinos and Watson, 2005) for electroencephalogram (EEG) recording, whereas a screw (ground) electrode was placed above the cerebellum. A stainless steel plate $(3 \mathrm{~mm} \times 4 \mathrm{~mm}$, one side insulated) was used as a reference electrode which was implanted under the skin and over the masseter muscle. All electrodes were soldered to a ten-pin socket.

To detect the well-known effect of LPS and IND on body temperature, aluminum holders containing thermo-resistors (Pt 100) were placed above the frontal bone (Kovács et al., 2006) of three - three animals of all animal groups (Table 1). We measured the body temperature with a thermometer (SUPERTECH, Hungary) in each $10 \mathrm{~min}$. Electrodes and aluminum holders were fixed to the skull bone with acrylic dental cement. Rats were allowed to recover from surgery for 2 weeks.

\subsubsection{EEG recording and SWD scoring}

Electroencephalogram was recorded by a differential biological amplifier (Bioamp4, Supertech Ltd., Pécs, Hungary) connected to a CED $1401 \mathrm{mII}$ data capture and analysis device. Spike2 software (CED, Cambridge, UK) was used for recording the EEG. To detect SWDs, frontal cortex - plate and parietal cortex - plate leads were recorded. The bandwidth of the EEG signal filtering was $0.53-150 \mathrm{~Hz}$. The analog signal was A/D converted at $1 \mathrm{kHz}$ sampling rate and raw EEG data were stored on a PC for further analysis (Kovács et al., 2006).

The main properties of a typical SWD of WAG/Rij rats, GAERS rats and Long Evans rats (WAG/Rij/GAERS/Long Evans) are as follows: power spectra 7-11/7-9/6-12 Hz (Fig. 1b, d and f), amplitude 0.2-1.0/0.3-1.0/0.1-2.0 mV, duration 1-30/5-60/1-40 s (Akman et al., 2010; Coenen and Van Luijtelaar, 2003; Depaulis and Van Luijtelaar, 2005; Polack and Charpier, 2006; Shaw, 2004). The number of SWDs may vary between 15-40/20-80/6-90 (per hour) in WAG/Rij rats, GAERS rats and Long Evans rats depending on the time of the day and age of animals (Akman et al., 2010; Coenen and Van Luijtelaar, 2003; Depaulis and Van Luijtelaar, 2005; Polack and Charpier, 2006; Shaw, 2004). To avoid the modulatory effect of age and sleep-wake cycle on SWD number, electrophysiological recordings were carry out on eight months old animals ( \pm 1 week) between 4.00 PM and 8.00 PM. In this relatively short period of circadian activity, the LPS evoked changes in SWD number are not the consequence of reduced waking state (Kovács et al., 2006). After the different treatments, the EEG recording periods were split into 60 min sections and evaluated separately (Kovács et al., 2006). The SWDs (Fig. 1a, c and e) were selected, and SWD numbers were measured in all animal groups (groups 1-12; Table 1). The durations of SWDs were also measured in animals treated i.p. LPS injection alone (groups 1-6; Table 1). Both i.p. injection and handling evoked stress could influence SWD number during first $30 \mathrm{~min}$ (Depaulis and Van Luijtelaar, 2005; Kovács et al., 2006, 2012). Consequently, the first half hour of data after the i.p. injections were not included into the analysis. In relation to individually different SWD number and duration (Kovács et al., 2006; Polack and Charpier, 2006; Shaw, 2004), the changes in SWD numbers and duration were expressed in percentage of average control measures (three-day 
Table 1

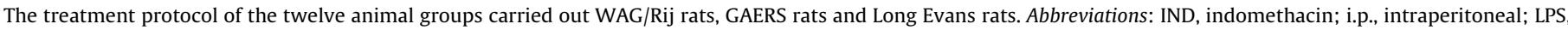
lipopolysaccharide; PTC day, post-treatment control day.

\begin{tabular}{|c|c|c|c|}
\hline \multirow[t]{2}{*}{ Animal groups } & \multicolumn{3}{|l|}{ Experimental design } \\
\hline & 1-3 days & 4th day & 5th day (PTC day) \\
\hline Group 1 (WAG/Rij; $n=5)$ & $\begin{array}{l}\text { 1st treatment: } 2 \mathrm{ml} \text { saline i.p. } \\
\text { 2nd treatment: } 30 \text { min later, } \\
1 \mathrm{ml} \text { saline i.p. }\end{array}$ & $\begin{array}{l}\text { 1st treatment: } 2 \mathrm{ml} \text { saline i.p. } \\
\text { 2nd treatment: } 30 \text { min later, } \\
50 \mu \mathrm{g} / \mathrm{kg} \text { LPS in } 1 \mathrm{ml} \text { saline i.p. }\end{array}$ & $\begin{array}{l}\text { 1st treatment: } 2 \mathrm{ml} \text { saline i.p } \\
\text { 2nd treatment: } 30 \text { min later, } \\
1 \mathrm{ml} \text { saline i.p. }\end{array}$ \\
\hline Group $2($ WAG/Rij; $n=5)$ & $\begin{array}{l}\text { 1st treatment: } 2 \mathrm{ml} \text { saline i.p. } \\
\text { 2nd treatment: } 30 \text { min later, } \\
1 \mathrm{ml} \text { saline i.p. }\end{array}$ & $\begin{array}{l}\text { 1st treatment: } 2 \mathrm{ml} \text { saline i.p. } \\
\text { 2nd treatment: } 30 \text { min later, } \\
350 \mu \mathrm{g} / \mathrm{kg} \text { LPS in } 1 \mathrm{ml} \text { saline i.p. }\end{array}$ & $\begin{array}{l}\text { 1st treatment: } 2 \mathrm{ml} \text { saline i.p } \\
\text { 2nd treatment: } 30 \text { min later, } \\
1 \mathrm{ml} \text { saline i.p. }\end{array}$ \\
\hline Group 3 (GAERS; $n=5$ ) & $\begin{array}{l}\text { 1st treatment: } 2 \mathrm{ml} \text { saline i.p. } \\
\text { 2nd treatment: } 30 \text { min later, } \\
1 \mathrm{ml} \text { saline i.p. }\end{array}$ & $\begin{array}{l}\text { 1st treatment: } 2 \mathrm{ml} \text { saline i.p. } \\
\text { 2nd treatment: } 30 \text { min later, } \\
50 \mu \mathrm{g} / \mathrm{kg} \text { LPS in } 1 \mathrm{ml} \text { saline i.p. }\end{array}$ & $\begin{array}{l}\text { 1st treatment: } 2 \mathrm{ml} \text { saline i.p. } \\
\text { 2nd treatment: } 30 \text { min later, } \\
1 \mathrm{ml} \text { saline i.p. }\end{array}$ \\
\hline Group 4 (GAERS; $n=5$ ) & $\begin{array}{l}\text { 1st treatment: } 2 \mathrm{ml} \text { saline i.p. } \\
\text { 2nd treatment: } 30 \text { min later, } \\
1 \mathrm{ml} \text { saline i.p. }\end{array}$ & $\begin{array}{l}\text { 1st treatment: } 2 \mathrm{ml} \text { saline i.p. } \\
\text { 2nd treatment: } 30 \mathrm{~min} \text { later, } \\
350 \mu \mathrm{g} / \mathrm{kg} \text { LPS in } 1 \mathrm{ml} \text { saline i.p. }\end{array}$ & $\begin{array}{l}\text { 1st treatment: } 2 \mathrm{ml} \text { saline i.p } \\
\text { 2nd treatment: } 30 \text { min later, } \\
1 \mathrm{ml} \text { saline i.p. }\end{array}$ \\
\hline Group 5 (Long Evans; $n=5$ ) & $\begin{array}{l}\text { 1st treatment: } 2 \mathrm{ml} \text { saline i.p. } \\
\text { 2nd treatment: } 30 \text { min later, } \\
1 \mathrm{ml} \text { saline i.p. }\end{array}$ & $\begin{array}{l}\text { 1st treatment: } 2 \mathrm{ml} \text { saline i.p. } \\
\text { 2nd treatment: } 30 \mathrm{~min} \text { later, } \\
50 \mu \mathrm{g} / \mathrm{kg} \text { LPS in } 1 \mathrm{ml} \text { saline i.p. }\end{array}$ & $\begin{array}{l}\text { 1st treatment: } 2 \mathrm{ml} \text { saline i.p } \\
\text { 2nd treatment: } 30 \text { min later, } \\
1 \mathrm{ml} \text { saline i.p. }\end{array}$ \\
\hline Group 6 (Long Evans; $n=5$ ) & $\begin{array}{l}\text { 1st treatment: } 2 \mathrm{ml} \text { saline i.p. } \\
\text { 2nd treatment: } 30 \text { min later, } \\
1 \mathrm{ml} \text { saline i.p. }\end{array}$ & $\begin{array}{l}\text { 1st treatment: } 2 \mathrm{ml} \text { saline i.p. } \\
\text { 2nd treatment: } 30 \mathrm{~min} \text { later, } \\
350 \mu \mathrm{g} / \mathrm{kg} \text { LPS in } 1 \mathrm{ml} \text { saline i.p. }\end{array}$ & $\begin{array}{l}\text { 1st treatment: } 2 \mathrm{ml} \text { saline i.p } \\
\text { 2nd treatment: } 30 \text { min later, } \\
1 \mathrm{ml} \text { saline i.p. }\end{array}$ \\
\hline Group 7 (WAG/Rij; $n=5)$ & $\begin{array}{l}\text { 1st treatment: } 2 \mathrm{ml} 5 \%(\mathrm{v} / \mathrm{v}) \\
\text { ethanol solution i.p. } \\
\text { 2nd treatment: } 30 \text { min later, } \\
1 \mathrm{ml} \text { saline i.p. }\end{array}$ & $\begin{array}{l}\text { 1st treatment: } 10 \mathrm{mg} / \mathrm{kg} \text { IND in } \\
2 \mathrm{ml} 5 \%(\mathrm{v} / \mathrm{v}) \text { ethanol solution i.p. } \\
\text { 2nd treatment: } 30 \mathrm{~min} \text { later, } 1 \mathrm{ml} \\
\text { saline i.p. }\end{array}$ & $\begin{array}{l}\text { 1st treatment: } 2 \mathrm{ml} 5 \%(\mathrm{v} / \mathrm{v}) \\
\text { ethanol solution i.p. } \\
\text { 2nd treatment: } 30 \mathrm{~min} \text { later, } \\
1 \mathrm{ml} \text { saline i.p. }\end{array}$ \\
\hline Group $8($ WAG/Rij; $n=5)$ & $\begin{array}{l}\text { 1st treatment: } 2 \mathrm{ml} 5 \%(\mathrm{v} / \mathrm{v}) \\
\text { ethanol solution i.p. } \\
\text { 2nd treatment: } 30 \text { min later, } \\
1 \mathrm{ml} \text { saline i.p. }\end{array}$ & $\begin{array}{l}\text { 1st treatment: } 10 \mathrm{mg} / \mathrm{kg} \text { IND in } \\
2 \mathrm{ml} 5 \%(\mathrm{v} / \mathrm{v}) \text { ethanol solution i.p. } \\
2 \mathrm{nd} \text { treatment: } 30 \mathrm{~min} \text { later, } \\
50 \mu \mathrm{g} / \mathrm{kg} \text { LPS in } 1 \mathrm{ml} \text { saline i.p }\end{array}$ & $\begin{array}{l}\text { 1st treatment: } 2 \mathrm{ml} 5 \%(\mathrm{v} / \mathrm{v}) \\
\text { ethanol solution i.p. } \\
\text { 2nd treatment: } 30 \mathrm{~min} \text { later, } \\
1 \mathrm{ml} \text { saline i.p. }\end{array}$ \\
\hline Group 9 (GAERS; $n=5$ ) & $\begin{array}{l}\text { 1st treatment: } 2 \mathrm{ml} 5 \%(\mathrm{v} / \mathrm{v}) \\
\text { ethanol solution i.p. } \\
\text { 2nd treatment: } 30 \text { min later, } \\
1 \mathrm{ml} \text { saline i.p. }\end{array}$ & $\begin{array}{l}\text { 1st treatment: } 10 \mathrm{mg} / \mathrm{kg} \text { IND in } \\
2 \mathrm{ml} 5 \%(\mathrm{v} / \mathrm{v}) \text { ethanol solution i.p. } \\
\text { 2nd treatment: } 30 \mathrm{~min} \text { later, } 1 \mathrm{ml} \\
\text { saline i.p. }\end{array}$ & $\begin{array}{l}\text { 1st treatment: } 2 \mathrm{ml} 5 \%(\mathrm{v} / \mathrm{v}) \\
\text { ethanol solution i.p. } \\
\text { 2nd treatment: } 30 \text { min later, } \\
1 \mathrm{ml} \text { saline i.p. }\end{array}$ \\
\hline Group 10 (GAERS; $n=5$ ) & $\begin{array}{l}\text { 1st treatment: } 2 \mathrm{ml} 5 \%(\mathrm{v} / \mathrm{v}) \\
\text { ethanol solution i.p. } \\
\text { 2nd treatment: } 30 \text { min later, } \\
1 \mathrm{ml} \text { saline i.p. }\end{array}$ & $\begin{array}{l}\text { 1st treatment: } 10 \mathrm{mg} / \mathrm{kg} \text { IND in } \\
2 \mathrm{ml} 5 \%(\mathrm{v} / \mathrm{v}) \text { ethanol solution i.p. } \\
2 \mathrm{nd} \text { treatment: } 30 \mathrm{~min} \text { later, } \\
50 \mu \mathrm{g} / \mathrm{kg} \text { LPS in } 1 \mathrm{ml} \text { saline i.p }\end{array}$ & $\begin{array}{l}\text { 1st treatment: } 2 \mathrm{ml} 5 \%(\mathrm{v} / \mathrm{v}) \\
\text { ethanol solution i.p. } \\
\text { 2nd treatment: } 30 \text { min later, } \\
1 \mathrm{ml} \text { saline i.p. }\end{array}$ \\
\hline Group 11 (Long Evans; $n=5$ ) & $\begin{array}{l}\text { 1st treatment: } 2 \mathrm{ml} 5 \%(\mathrm{v} / \mathrm{v}) \\
\text { ethanol solution i.p. } \\
\text { 2nd treatment: } 30 \text { min later, } \\
1 \mathrm{ml} \text { saline i.p. }\end{array}$ & $\begin{array}{l}\text { 1st treatment: } 10 \mathrm{mg} / \mathrm{kg} \text { IND in } \\
2 \mathrm{ml} 5 \%(\mathrm{v} / \mathrm{v}) \text { ethanol solution i.p. } \\
\text { 2nd treatment: } 30 \mathrm{~min} \text { later, } 1 \mathrm{ml} \\
\text { saline i.p. }\end{array}$ & $\begin{array}{l}\text { 1st treatment: } 2 \mathrm{ml} 5 \%(\mathrm{v} / \mathrm{v}) \\
\text { ethanol solution i.p. } \\
\text { 2nd treatment: } 30 \text { min later, } \\
1 \mathrm{ml} \text { saline i.p. }\end{array}$ \\
\hline Group 12 (Long Evans; $n=5$ ) & $\begin{array}{l}\text { 1st treatment: } 2 \mathrm{ml} 5 \%(\mathrm{v} / \mathrm{v}) \\
\text { ethanol solution i.p. } \\
\text { 2nd treatment: } 30 \mathrm{~min} \text { later, } \\
1 \mathrm{ml} \text { saline i.p. }\end{array}$ & $\begin{array}{l}\text { 1st treatment: } 10 \mathrm{mg} / \mathrm{kg} \text { IND in } \\
2 \mathrm{ml} 5 \%(\mathrm{v} / \mathrm{v}) \text { ethanol solution i.p. } \\
2 \text { nd treatment: } 30 \mathrm{~min} \text { later, } \\
50 \mu \mathrm{g} / \mathrm{kg} \text { LPS in } 1 \mathrm{ml} \text { saline i.p }\end{array}$ & $\begin{array}{l}\text { 1st treatment: } 2 \mathrm{ml} 5 \%(\mathrm{v} / \mathrm{v}) \\
\text { ethanol solution i.p. } \\
\text { 2nd treatment: } 30 \mathrm{~min} \text { later, } \\
1 \mathrm{ml} \text { saline i.p. }\end{array}$ \\
\hline
\end{tabular}

control period) and evaluated by ANOVA. Data are expressed as means \pm S.E.M.

\subsubsection{Experimental design: application of LPS and IND}

Animals were assigned into twelve groups $(n=5-5)$ and treated as follows (Table 1). To establish average control SWD levels, animals were injected for three days (three-day control period) with $2 \mathrm{ml}$ saline i.p. (1 st injection, 1-3 days, groups 1-6)(Table 1 ) or with $2 \mathrm{ml} \mathrm{5 \% (v/v)} \mathrm{ethanol} \mathrm{solution} \mathrm{i.p.} \mathrm{(1st} \mathrm{injection,} \mathrm{1-3} \mathrm{days,} \mathrm{groups}$ 7-12) (Table 1) because IND (Sigma, Germany) which was injected on the fourth day dissolves in $5 \%(\mathrm{v} / \mathrm{v})$ ethanol solution (Table 1$)$. Thirty min later, all animals received $1 \mathrm{ml}$ saline i.p. (2nd injection, 1-3 days, groups $1-12$ ) (Table 1 ).

The animals in groups 1-6 received $2 \mathrm{ml}$ saline i.p. (1st injection) and $30 \mathrm{~min}$ later, $50 \mu \mathrm{g} / \mathrm{kg}$ LPS in $1 \mathrm{ml}$ saline (groups $1,3,5$ ) or $350 \mu \mathrm{g} / \mathrm{kg}$ LPS in $1 \mathrm{ml}$ saline (groups 2, 4, 6) were i.p. injected (2nd injection) on the fourth day (Table 1 ). To examine the possible long lasting effects of LPS, on the fifth day, all animals of groups 1-6 were injected with $2 \mathrm{ml}$ saline i.p. (1st injection) and 30 min later (2nd injection) with $1 \mathrm{ml}$ saline (post-treatment control experiments/day: PTC day)(Table 1). In case of the groups 7-12, on the fourth day, animals received $10 \mathrm{mg} / \mathrm{kg}$ IND (i.p.) dissolved in $2 \mathrm{ml} 5 \%(\mathrm{v} / \mathrm{v})$ ethanol in saline (1st injection), which was followed (2nd injection) by $1 \mathrm{ml}$ saline i.p. (groups $7,9,11$ ) or by $50 \mu \mathrm{g} / \mathrm{kg}$
LPS in $1 \mathrm{ml}$ saline i.p. (groups 8, 10, 12) 30 min later (Table 1). In animals of groups $7-12$, on the fifth day, a post-treatment control experiment was also performed by i.p. injection of $2 \mathrm{ml} 5 \%(\mathrm{v} / \mathrm{v})$ ethanol solution (1st injection) and $1 \mathrm{ml}$ saline (2nd injection; PTC day) (Table 1 ).

\section{Results}

\subsection{Effect of LPS on body temperature and on SWD number and SWD duration}

Intraperitoneal application of $50 \mu \mathrm{g} / \mathrm{kg}$ LPS and $350 \mu \mathrm{g} / \mathrm{kg}$ LPS initially decreased and increased body temperature for about 40-60 min after injection, respectively, following by a rapid elevation and reduction of body temperature similarly in all investigated rat strains and groups (Fig. 2a-f; Table 1: groups 1-6). The body temperature continuously increased $(50 \mu \mathrm{g} / \mathrm{kg}$ LPS $)$ and decreased (350 $\mu \mathrm{g} / \mathrm{kg}$ LPS) and reached their highest levels (about $0.6-0.8^{\circ} \mathrm{C}$ above basal level) between 120 and $190 \mathrm{~min}$ ( $50 \mu \mathrm{g} / \mathrm{kg}$ LPS, Fig. 2a, $\mathrm{C}$ and e) and lowest levels (about $0.7-0.9^{\circ} \mathrm{C}$ below basal level) at $140 \mathrm{~min}$ (WAG/Rij rats), $210 \mathrm{~min}$ (GAERS rats) and $200 \mathrm{~min}$ (Long Evans rats) $(350 \mu \mathrm{g} / \mathrm{kg}$ LPS, Fig. $2 \mathrm{~b}, \mathrm{~d}$ and f). Body temperature remained elevated ( $50 \mu \mathrm{g} / \mathrm{kg}$ LPS) or decreased ( $350 \mu \mathrm{g} / \mathrm{kg}$ LPS) until the end of the measurement ( $270 \mathrm{~min})$. 

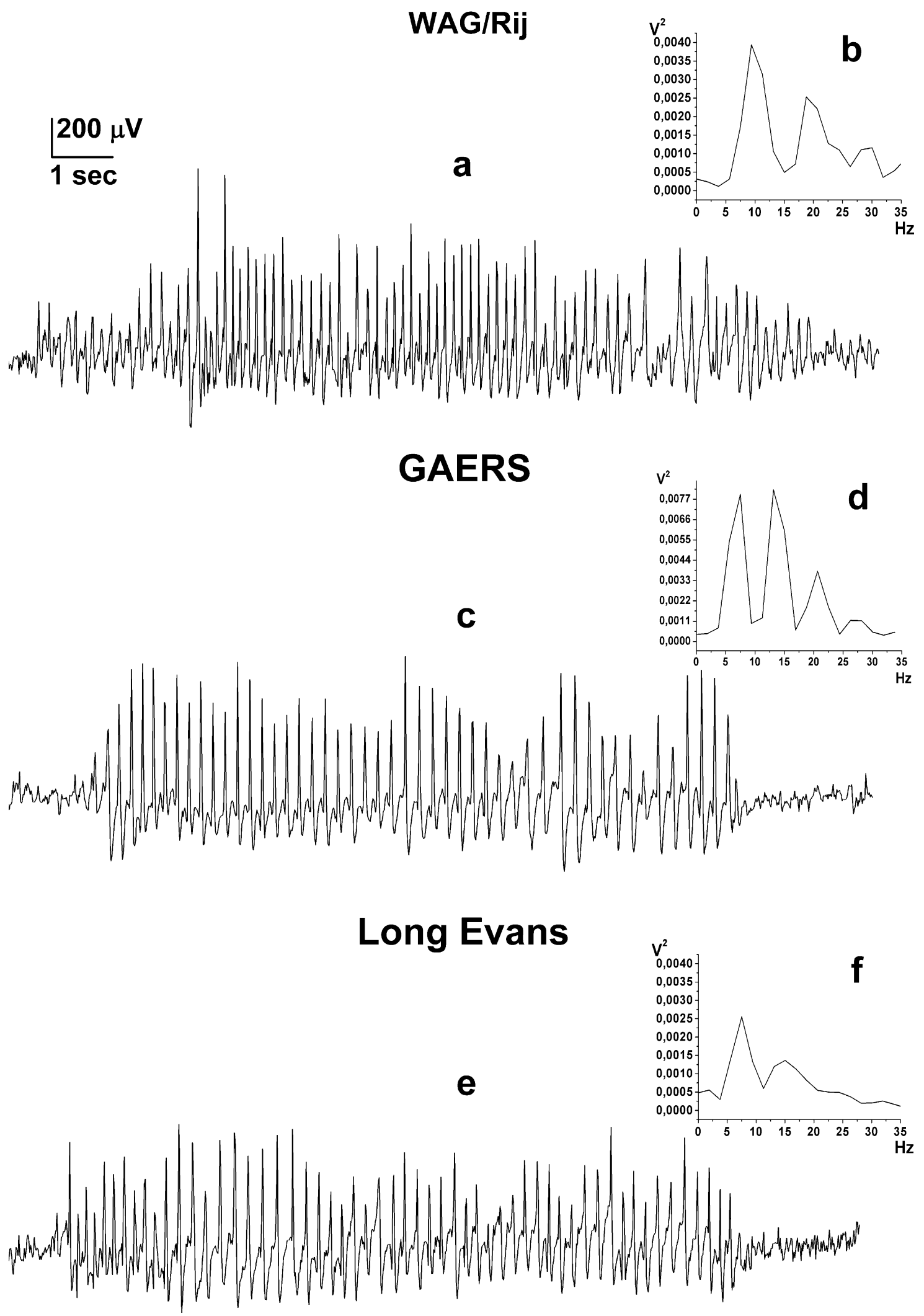

Fig. 1. Typical SWDs (a, c, e) and their power spectrum (b, d, f) recorded from freely moving WAG/Rij rats, GAERS rats and Long Evans rats on the control days.

Both doses of LPS (i.p. $50 \mu \mathrm{g} / \mathrm{kg}$ LPS and $350 \mu \mathrm{g} / \mathrm{kg}$ LPS) significantly increased the number of SWDs in all animal strains (Fig. 3a-f; Table 1: groups 1-6). However, several small differences were observed among the three rat strains in relation to the time course of LPS evoked effects on SWD number. After the rapid elevation of SWD number in WAG/Rij rats and Long Evans rats (WAG/Rij and Long Evans; 30-90 min after injection: $193.5 \pm 17.9 \%$ and $169.3 \pm 9.9 \%$ compared to the three-day 
$350 \mu \mathrm{g} / \mathrm{kg}$ LPS

\section{WAG/Rij}
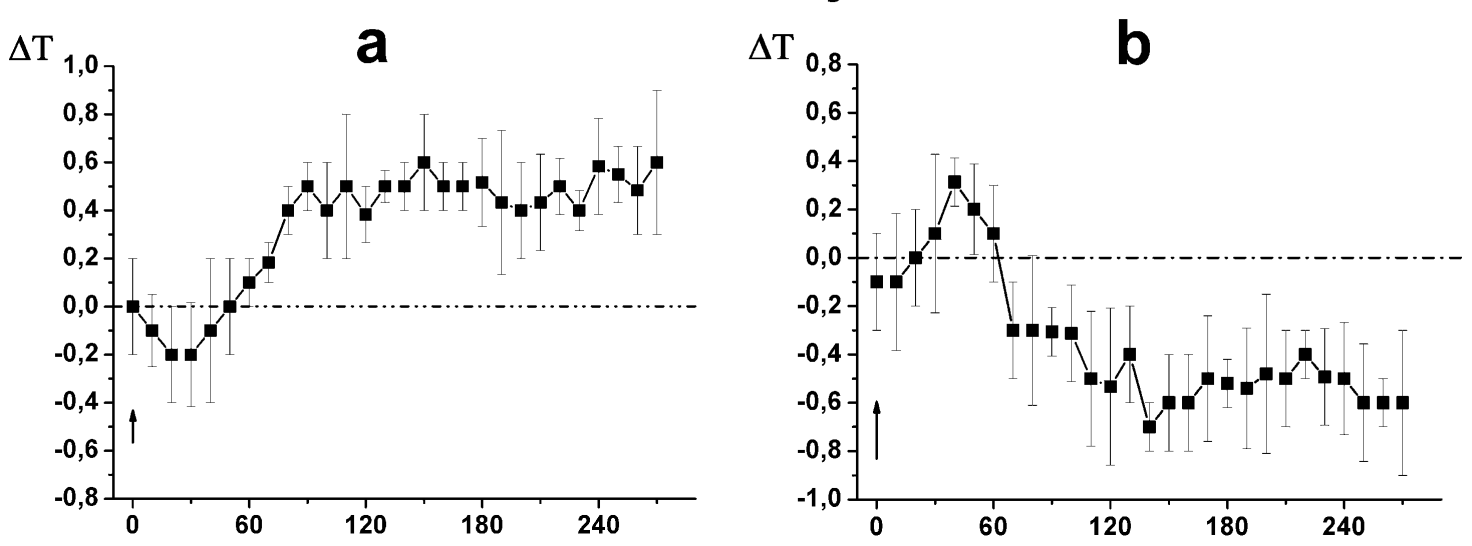

\section{GAERS}
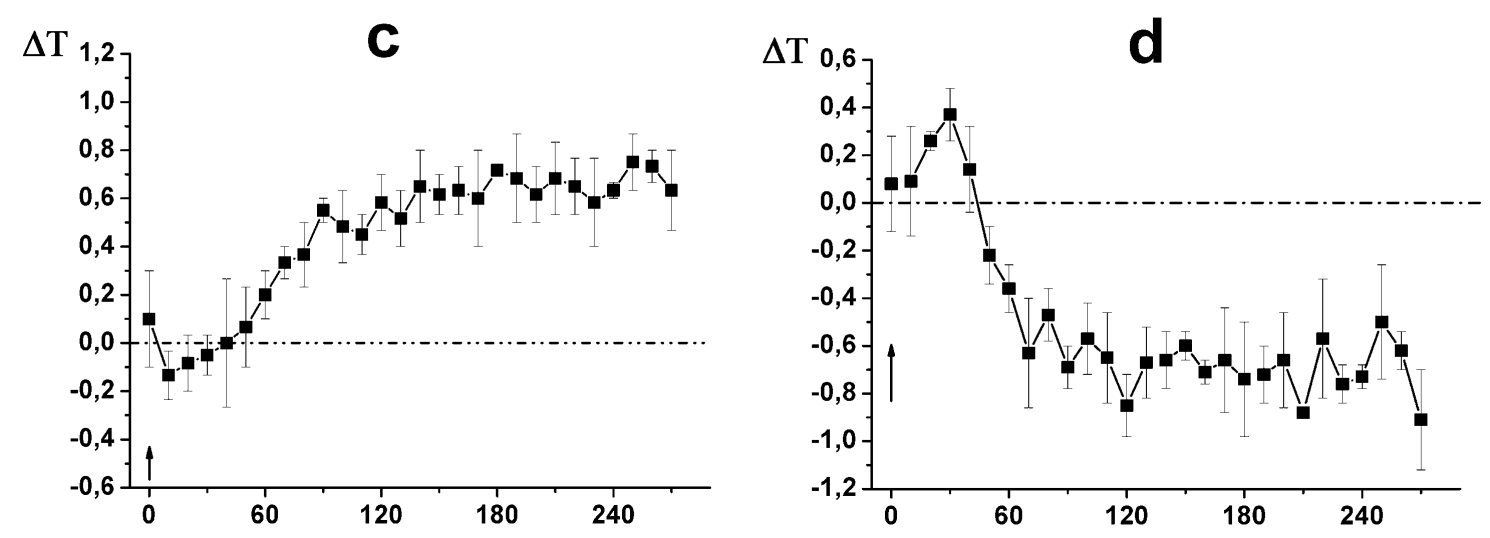

\section{Long Evans}
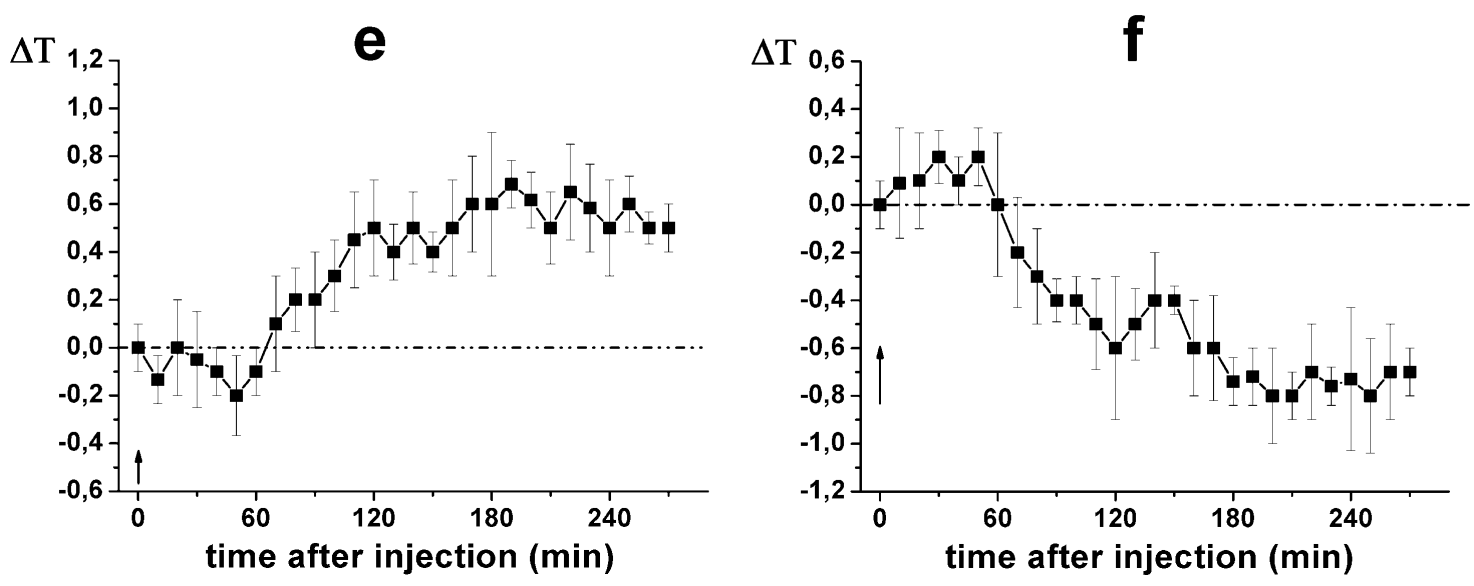

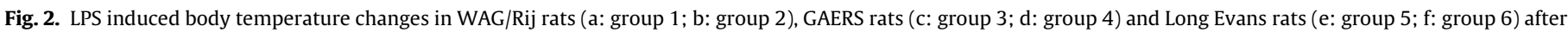
i.p. injection of two doses of LPS $(50 \mu \mathrm{g} / \mathrm{kg}$ and $350 \mu \mathrm{g} / \mathrm{kg})$. Arrows indicate the time of i.p. injection $(0 \mathrm{~min})$.

control period), the SWD number increased until 90-150/150 $210 \mathrm{~min}$ (WAG/Rij and Long Evans; 90-150 min: $314.7 \pm 38.8 \%$ and $282.1 \pm 39.4 \%$, $150-210 \mathrm{~min}: 305.9 \pm 57.3 \%$ and $307.2 \pm 38.2 \%)$ following slight decrease in SWD numbers (WAG/Rij and Long Evans; $275.8 \pm 37.4 \%$ and $279.8 \pm 52.2$ ) between 210 and $270 \mathrm{~min}$ (Fig. 3a and e). However, in GAERS rats, SWD number remained at similarly high level between 30-90 (206.6 $\pm 24.5 \%)$ and $90-150 \mathrm{~min}$ $(208.3 \pm 23.3 \%)$ followed by a slight decrease in the number of SWDs (150-210 min: $171.5 \pm 26.7 \%, 210-270 \mathrm{~min}: 163.2 \pm 21.2 \%$ ) (Fig. 3c). In case of higher dose of LPS $(350 \mu \mathrm{g} / \mathrm{kg} \mathrm{LPS})$, the 

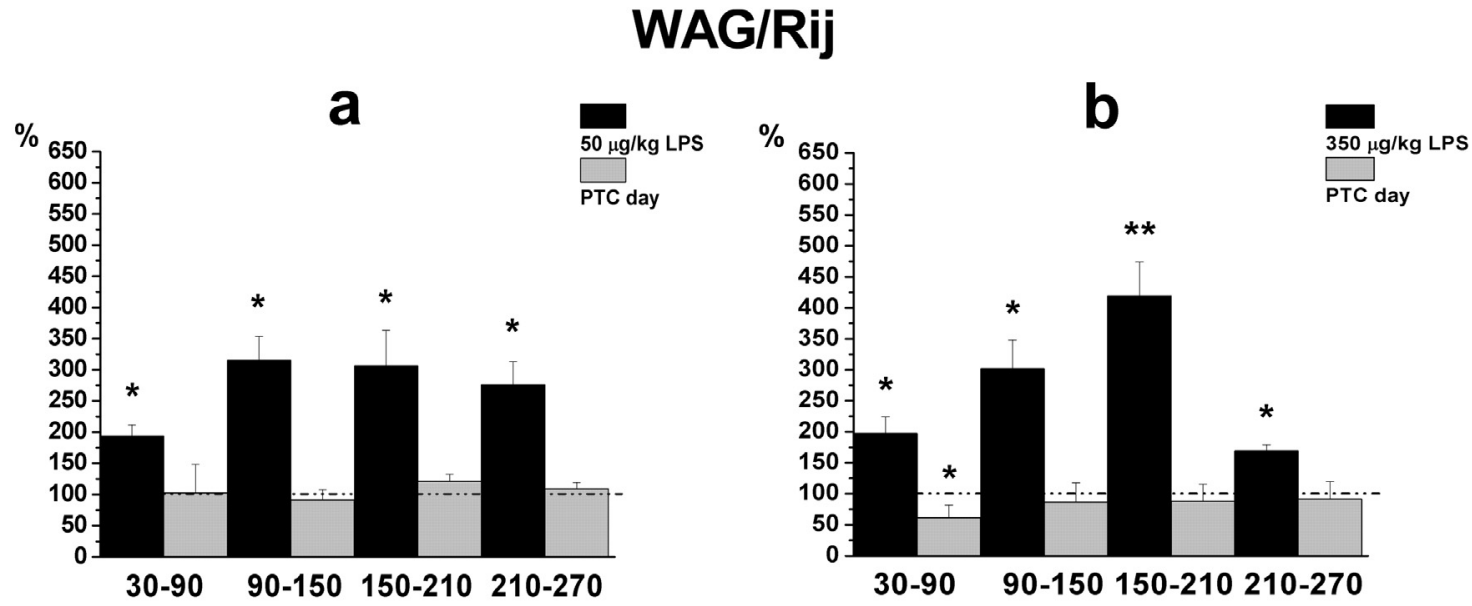

\section{GAERS}
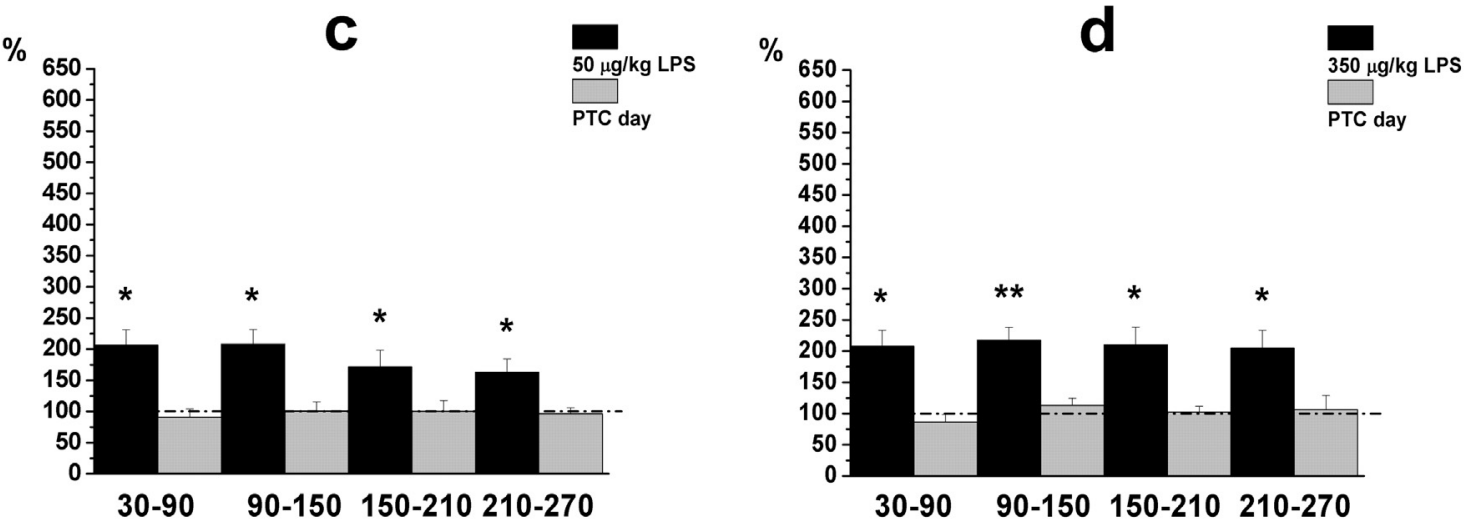

\section{Long Evans}
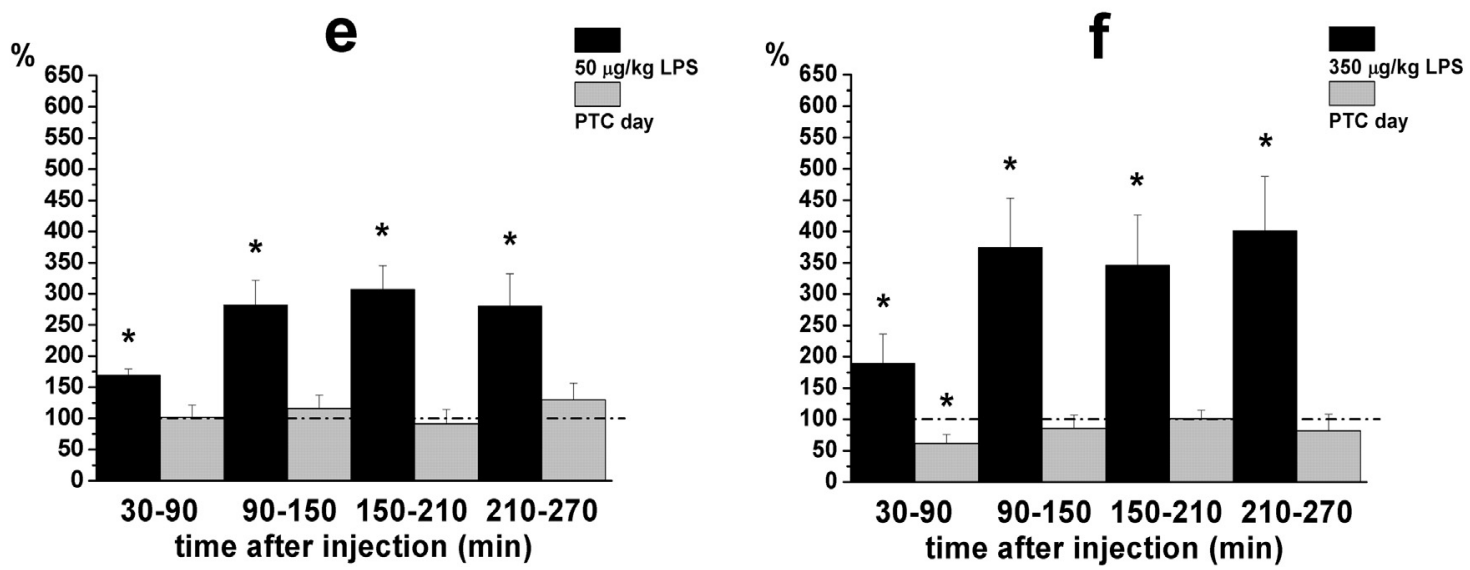

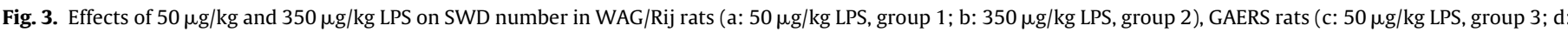

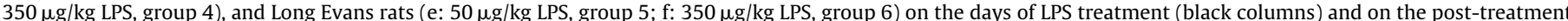

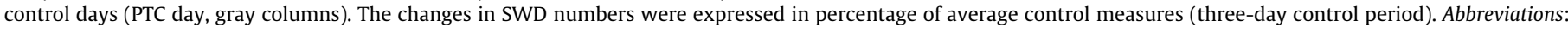
LPS, lipopolysaccharide; PTC day, post-treatment control day. * Labels $p<0.05$ and ${ }^{* *}$ labels $p<0.005$ level of significance.

SWD numbers (i) increased continuously between 30 and 210 min (30-90 min: $197.2 \pm 26.9 \%, 90-150$ min: $301.8 \pm 46.5 \%, 150-210$ : $419.4 \pm 54.7 \%)$ after i.p. injection following a rapid decrease (210-270 min: $169.1 \pm 10.0 \%$ ) in WAG/Rij rats, (ii) remained at similarly elevated level between 30 and $270 \mathrm{~min}$ (30-90 min:
$207.9 \pm 25.6 \%, 90-150 \mathrm{~min}: 217.6 \pm 20.6 \%, 150-210: 210.4 \pm 28.5 \%$, 210-270 min: $204.7 \pm 28.9 \%$ ) in GAERS rats and (iii) increased for $150 \mathrm{~min}$ (30-90 min: $189.0 \pm 47.1 \%$, 90-150 min: $374.4 \pm 78.7 \%$ ) and remained at high level (150-210: $346.0 \pm 80.5 \%, 210-270 \mathrm{~min}$ : $400.9 \pm 86.6 \%$ ) in Long Evans rats (Fig. $3 \mathrm{~b}, \mathrm{~d}$ and $\mathrm{f}$ ). In addition, the 
higher dose of LPS ( $350 \mu \mathrm{g} / \mathrm{kg}$ LPS) was not able to evoke higher increase in SWD number than the smaller dose ( $50 \mu \mathrm{g} / \mathrm{kg}$ LPS) did in GAERS rats (Fig. 3c and d). After i.p. injection of $50 \mu \mathrm{g} / \mathrm{kg}$ LPS, on the PTC day, the SWD number returned to the baseline level in all animal strains (Fig. 3a, c and e). In relation to injection of the higher dose of LPS ( $350 \mu \mathrm{g} / \mathrm{kg}$ LPS), on the PTC day, decreased SWD numbers were detected between 30 and $90 \mathrm{~min}$ in WAG/Rij rats $(61.4 \pm 20.4 \%)$ and Long Evans rats $(61.8 \pm 14.3 \%)$ whereas only a slight lowering in SWD number $(86.3 \pm 12.5 \%)$ was observed in the first measuring hour in GAERS rats (Fig. $3 \mathrm{~b}$, $\mathrm{d}$ and $\mathrm{f}$ ).

The total time of SWDs significantly increased in parallel with the change in SWD number between 30 and 270 min after LPS injection in WAG/Rij rats, GAERS rats and Long Evans rats, which is in agreement with the result that average time of SWDs did not change significantly (Fig. 4; Table 1: groups 1-6).

\subsection{Effect of IND alone and in combination with LPS on SWD number and body temperature}

Indomethacin ( $10 \mathrm{mg} / \mathrm{kg}$ i.p.) alone significantly decreased the number of SWDs in the first $2 \mathrm{~h}$ of the recordings in WAG/Rij rats (30-90 min: $31.0 \pm 9.2 \%, 90-150 \mathrm{~min}: 45.8 \pm 14.6 \%$ ), GAERS rats (30-90 min: $46.0 \pm 11.2 \%, 90-150 \mathrm{~min}: 62.8 \pm 14.6 \%$ ) and Long Evans rats (30-90 min: $26.0 \pm 6.2 \%, 90-150 \mathrm{~min}: 55.8 \pm 11.6 \%)$ rats (Fig. 5a, c and e: $10 \mathrm{mg} / \mathrm{kg}$ IND; Table 1: groups 7, 9 and 11). By pretreatment with IND $(10 \mathrm{mg} / \mathrm{kg}$ i.p.) $30 \mathrm{~min}$ before the i.p. LPS injection $(50 \mu \mathrm{g} / \mathrm{kg})$ SWD number increasing effect of LPS was completely abolished in all animal strains (Fig. 5a, c and e: IND+LPS; Table 1: groups 8, 10 and 12).

Indomethacin ( $10 \mathrm{mg} / \mathrm{kg}$ i.p.) injected alone had no effect on body temperature in any animal strain (Fig. $5 \mathrm{~b}$, d and f: $10 \mathrm{mg} / \mathrm{kg}$ IND; Table 1: groups 7, 9 and 11) whereas IND (10 mg/kg i.p.) pretreatment $30 \mathrm{~min}$ before LPS injection ( $50 \mu \mathrm{g} / \mathrm{kg}$ LPS i.p.) abolished the LPS evoked increase in body temperature (Fig. 5b, $\mathrm{d}$ and $\mathrm{f}$ : IND + LPS; Table 1: groups 8, 10 and 12).

\section{Discussion}

The major finding of our study was that we were able to strengthen our previous results in WAG/Rij rats and extend them to two other absence epileptic rats (GAERS and Long Evans), such as: (i) i.p. injection of single doses of LPS enhanced the seizure activity and changed the body temperature dose-dependently, and (ii) IND pretreatment abolished the LPS treatment evoked changes in body temperature and SWD number.

The genetically absence epileptic WAG/Rij rats and GAERS rats are well established models of human absence epilepsy (Depaulis and Van Luijtelaar, 2005; Van Luijtelaar et al., 2011). It is interesting to note that not only WAG/Rij rats and GAERS rats but also Long Evans rats produce SWDs: spontaneous high-voltage rhythmic spike (HVRS) discharges of Long Evans rats in EEG recordings may be considered as SWDs as was demonstrated by analysis of pharmacological, behavioral and EEG features of HVRS activity (Depaulis and Van Luijtelaar, 2005; Huang et al., 2012; Polack and Charpier, 2006; Shaw, 2004, 2007; Shaw et al., 2009; Van Luijtelaar et al., 2011). However, additional studies (e.g., pharmacological and electrophysiological) are needed to investigate the similarities/differences in the features of absence epileptic activity between WAG/Rij rats, GAERS rats and Long Evans rats in order to include the Long Evans rat strain in the widely accepted models of human absence epilepsy. According to literature, Long Evans rats may be considered as a model animal of absence epilepsy only to some extent at the moment (Depaulis and Van Luijtelaar, 2005; Huang et al., 2012; Kovács et al., 2013; Polack and Charpier, 2006; Shaw, 2004, 2007; Shaw et al., 2009; Van Luijtelaar et al., 2011). A typical SWD contains train of spikes and slow waves starting and ending with spikes in all absence epileptic rats, but some differences in features of SWDs in GAERS rats, WAG/Rij rats and Long Evans rats have been revealed. For example, first SWDs emerge after 30th days and between 60 and 80 days in GAERS rats and WAG/Rij rats, respectively (Akman et al., 2010; Coenen and Van Luijtelaar, 2003; Depaulis and Van Luijtelaar, 2005). There are also similarities with some differences between the 3 strains as far as the mechanisms of SWDs. It has been demonstrated, that (i) several neurotransmitter systems are involved in the pathophysiological processes leading to absence epileptic seizures and their maintenance/recurrence such as glutamatergic system, GABAergic system, dopaminergic and nucleosiderg system in GAERS rats, WAG/Rij rats and Long Evans rats (Bazyan and Van Luijtelaar, 2013; Depaulis and Van Luijtelaar, 2005; Kovács et al., 2013, 2014; Li et al., 2006; Polack and Charpier, 2006), (ii) the effects of anti-epileptic drugs on SWDs were similar in GAERS rats, WAG/Rij rats and Long Evans rats (e.g., ethosuximide, and valproate decreased the number of SWDs) (Chen et al., 2011; Depaulis and Van Luijtelaar, 2005; Shaw, 2004, 2007), (iii) sodium channel (Nav1.1 and Nav1.6) expression was selectively increased in the somatosensory cortex of WAG/Rij rats in relation to age-dependent increase in seizure number and duration (Klein et al., 2004), (iv) selective decrease in thalamic (e.g., reticular thalamic nucleus) and cortical (e.g., somatosensory cortex) $G_{A B A}(A)$ receptor subunits such as reduction of $\alpha 3$ subunit of $G A B A_{(A)}$ receptor in reticular thalamic nucleus of WAG/Rij rats (Liu et al., 2007) may have a role in the pathophysiology of absence epilepsy in Long Evans rats, WAG/Rij rats and GAERS rats (Li et al., 2006; Spreafico et al., 1993), (v) mRNA levels for most $\mathrm{GABA}_{(\mathrm{B}(1))}$ subunits were lower in WAG/Rij neocortex than in cortex of control nonepileptic rats, which can contribute to neocortical hyperexcitability and SWD generation (Merlo et al., 2007) whereas $\mathrm{GABA}_{(\mathrm{B}(1))}$ subunit mRNA levels were higher and lower in the somatosensory cortex and ventrobasal thalamic nuclei of GAERS rats, respectively, compared with control animals (Princivalle et al., 2003), (vi) decreased alpha-amino-3-hydroxy-5-methyl-4-isoazolepropionic acid receptor (AMPA; AMPA-GluR4) and N-methyl-D-aspartate receptor (NMDA; NMDA-NR1) expression in the cortical focus of WAG/Rij animals (compared with non-epileptic control rats) and increased AMPA-GluR1/2 expression in GAERS rats in the somatosensory cortex may be in relation to hyperexcitability in somatosensory cortex and to SWD initiation (Van de BovenkampJanssen et al., 2006; Kennard et al., 2011), (vii) reduction of group-I metabotropic glutamate receptors (mGlu1 receptors) in ventrobasal thalamic nuclei and increased expression of group-II metabotropic glutamate receptors (mGlu2/3 receptors) in WAG/Rij rat somatosensory cortex and ventrobasal thalamic nuclei may be involved in the generation of SWDs (Ngomba et al., 2005, 2011), (viii) levels of dopaminergic (e.g., D1 and D2) receptor expression in different striatal and cortical structures implicated in control of absence epilepsy were changed in WAG/Rij rats and GAERS rats (Birioukova et al., 2005; Jones et al., 2010), (ix) expression of hyperpolarization-activated cyclic nucleotide-gated cation channel (HCN; HCN1) was reduced in somatosensory cortex in WAG/Rij rats and increased in thalamocortical cells in both WAG/Rij rats and GAERS rats in relation to development and onset of cortical hyperexcitability and epileptogenesis as well as prolonged generation and termination of SWDs (Budde et al., 2005; Kuisle et al., 2006; Strauss et al., 2004) and (x) changes in T-type $\mathrm{Ca}^{2+}$ channels (e.g., increase in expression of T-type $\mathrm{Ca}^{2+}$ channels and mutations of different $\mathrm{T}$-type $\mathrm{Ca}^{2+}$ channel genes in thalamic areas) may be in relation to increased absence epileptic activity in both WAG/Rij rats and GAERS rats (Broicher et al., 2008; Powell et al., 2009). In spite of some differences revealed, the anatomical, neurochemical and electrophysiological background of seizure initiation, seizure maintenance and cessation may be similar in GAERS rats, 

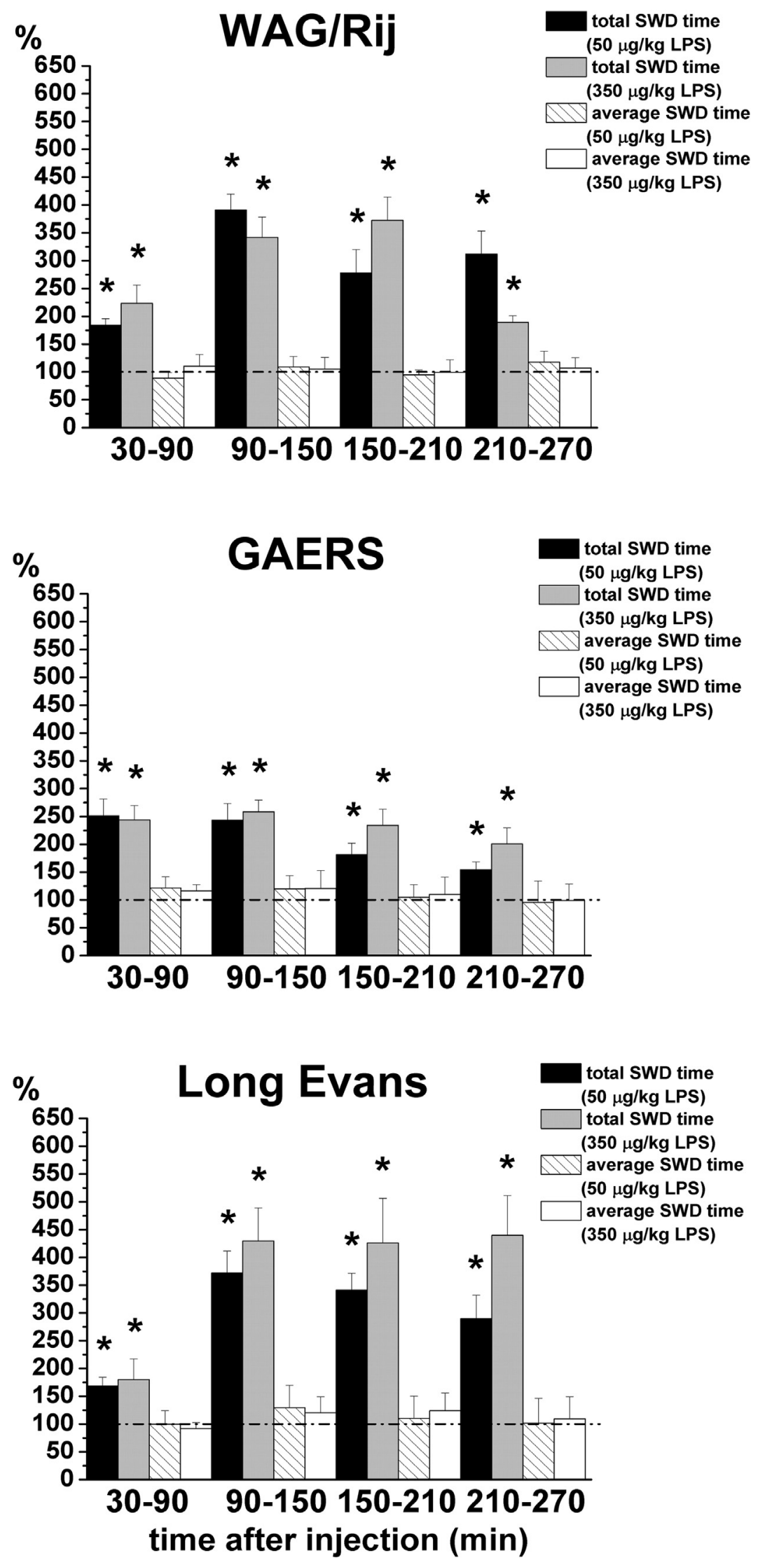

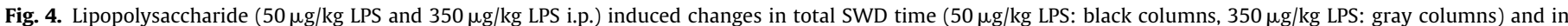

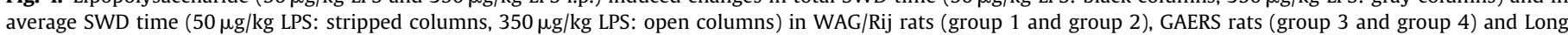

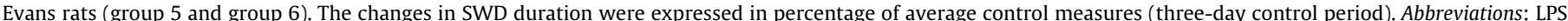
lipopolysaccharide; SWD: spike-wave discharge. * Labels $p<0.05$ level of significance. 


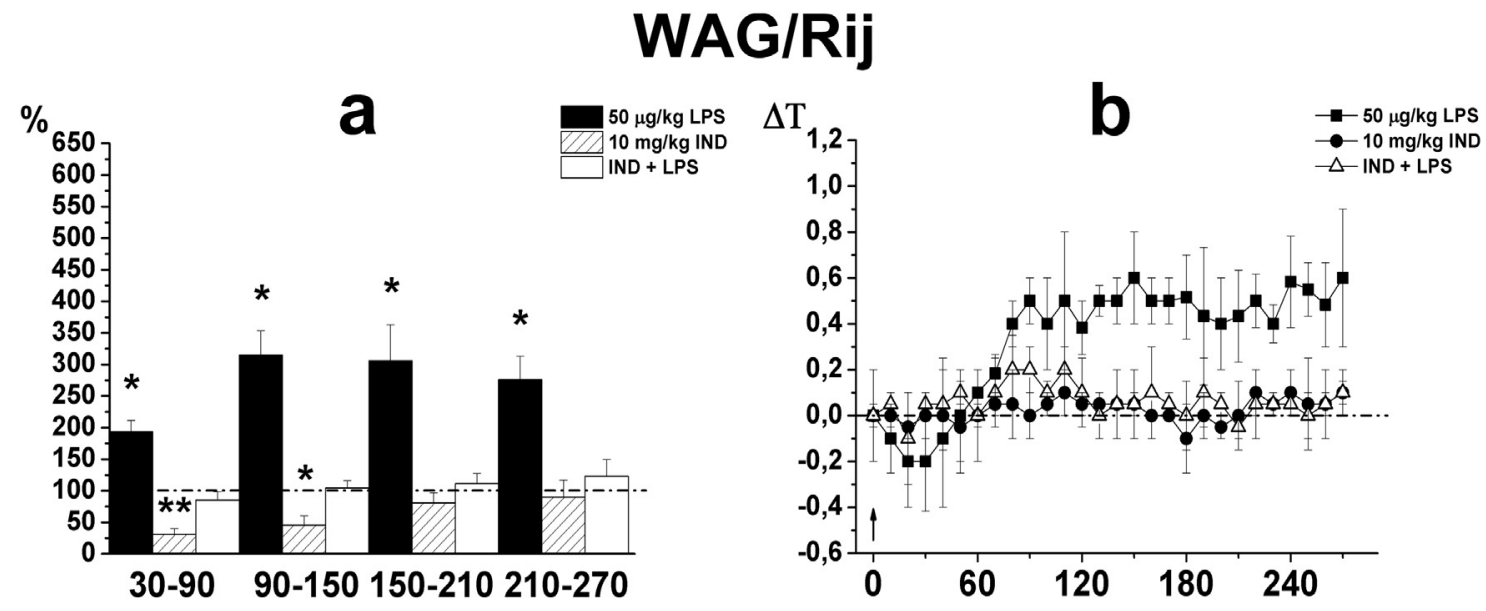

\section{GAERS}
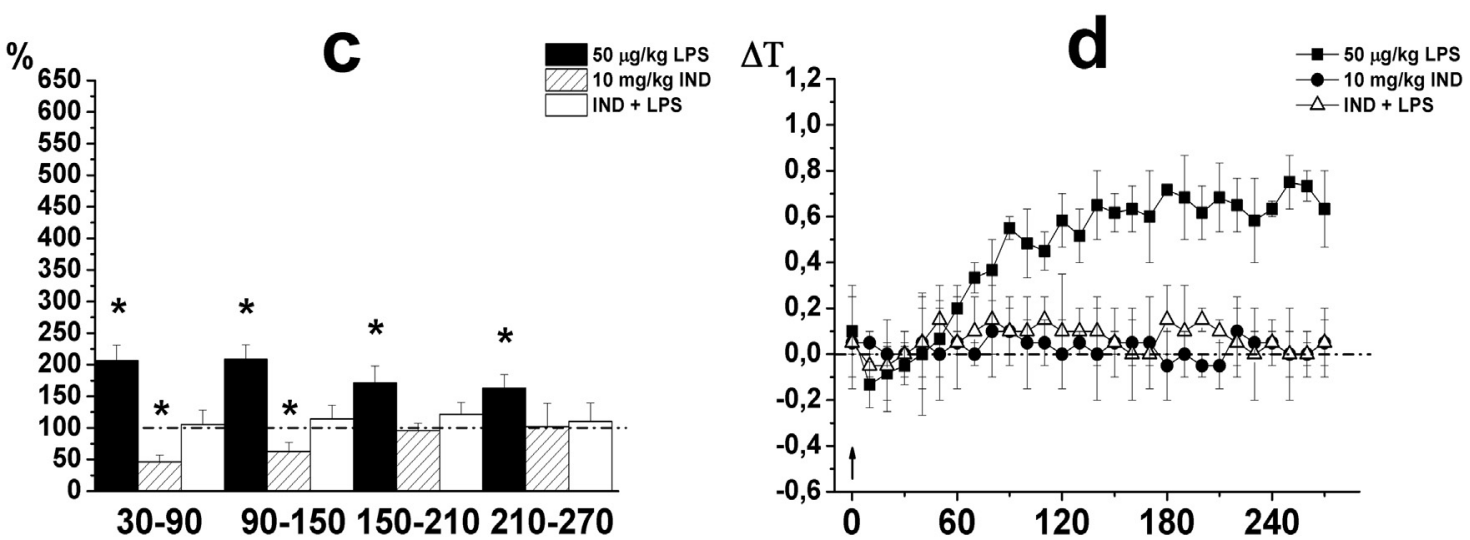

\section{Long Evans}
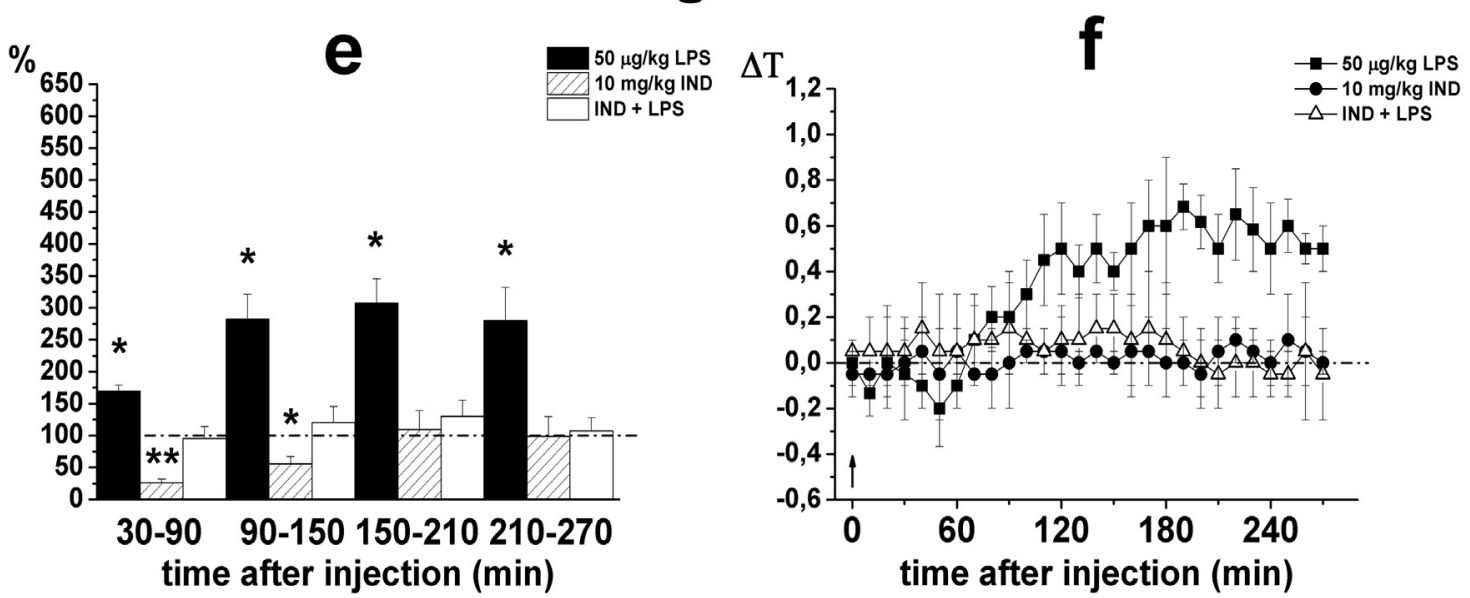

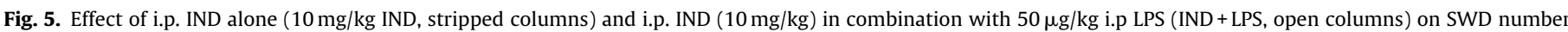

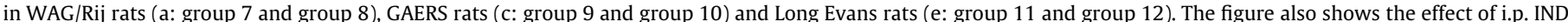

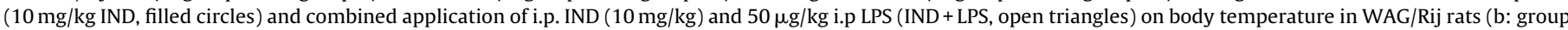

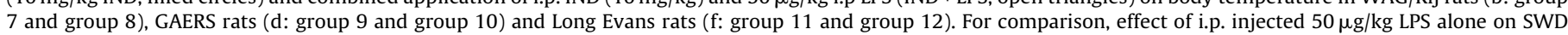

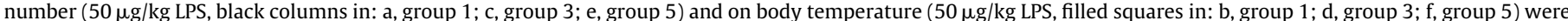

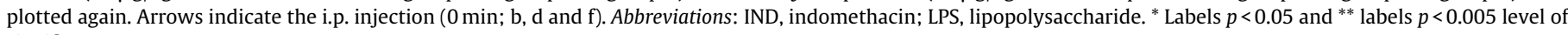
significance. 
WAG/Rij rats and Long Evans rats: the spontaneously generated absence-like seizures arise from the hyperexcitable focal cortical zone (cortical focus) in the somatosensory cortex, rapidly spread to other cortical and thalamic areas via intracortical networks and corticothalamic connections, respectively, and manifest in SWDs in EEG (Chen et al., 2011; Coenen and Van Luijtelaar, 2003; Depaulis and Van Luijtelaar, 2005; Polack and Charpier, 2006; Shaw, 2004; Van Luijtelaar et al., 2011). It was demonstrated, that the cortical focus leads the thalamus during the first $500 \mathrm{~ms}$ of the SWD. Subsequently, the cortical focus and the thalamus drive each other by cortico-thalamo-cortical oscillatory networks (Depaulis and Van Luijtelaar, 2005; Meeren et al., 2002).

Lipopolysaccharide evoked effects may be mediated by the IL-1 $\beta$, COX-2/prostaglandin $\mathrm{E}_{2}\left(\mathrm{PGE}_{2}\right)$ system and IL-1R/TLR signaling in the CNS. It was revealed that different doses of LPS may evoke changes in body temperature through the IL-1 $\beta$, COX-2/PGE 2 system (Huang et al., 2010; Kovács et al., 2006; Mlodzikowska-Albrecht et al., 2007), which can be inhibited by preceding application of the COX-2 inhibitor IND (Hashimoto et al., 1998; Kovács et al., 2006, 2011). Indomethacin alone had no effect on body temperature whereas its combined injection with LPS significantly decreased fever (Dogan et al., 2002; Kovács et al., 2011).

The i.p. injected LPS can induce cerebral inflammation via increased blood level of cytokines and inflammatory mediators and through direct action on brain cells (Kovács et al., 2006; Riazi et al., 2010; Rivest, 2003; Vezzani and Granata, 2005). The activated innate immune system (glycosylphosphatidylinositolanchored glycoprotein CD14, accessory protein MD-2 and TLR4) can generate immune response in the brain (Vezzani et al., 2011; Vezzani and Granata, 2005). Lipopolysaccharide evoked increased expression in TLR4, IL-1 $\beta$ and TNF- $\alpha$ in the brain within several hours (Eriksson et al., 2000; Goralski et al., 2005; Turrin et al., 2001; Vezzani et al., 2011) and glial release of proinflammatory cytokines (e.g., IL-1 $\beta$ and TNF- $\alpha$ ) through TLR4 was also demonstrated (Mlodzikowska-Albrecht et al., 2007; Rodgers et al., 2009; Vezzani et al., 2011). IL-1 $\beta$ and TNF- $\alpha$ may diminish the chloride current and may enlarge excitatory glutamatergic neurotransmission (Mlodzikowska-Albrecht et al., 2007; Vezzani and Granata, 2005) causing decreased seizure threshold and enhanced neuronal hyperexcitability (Riazi et al., 2010; Rodgers et al., 2009; Vezzani et al., 2011, 2013). In addition, $\mathrm{GABA}_{(\mathrm{A})}$-mediated inhibition decreasing influence and AMPA-dependent excitation increasing effect of TNF$\alpha$ were also demonstrated (Mlodzikowska-Albrecht et al., 2007; Vezzani et al., 2008). Imbalanced intracortical inhibitory and excitatory mechanisms result in cortical hyperexcitability during SWDs (Chen et al., 2011; Coenen and Van Luijtelaar, 2003; Depaulis and Van Luijtelaar, 2005; Van Luijtelaar et al., 2011). Thus, as a consequence of LPS/cytokine evoked increase in neuronal excitability and IL-1R expression on thalamic neurons and in the cortex (Wang et al., 1997; Yabuuchi et al., 1994), i.p. LPS injection evoked IL-1 $\beta$ release can enhance the excitation in the thalamo-cortical/corticothalamic circuitry, which could aggravate epileptic seizure activity in absence epileptic rats (Kovács et al., 2006; Snead, 1995). Little is known about the exact role of cytokines, such as IL-1 $\beta$ and TNF- $\alpha$ in absence epilepsy genesis/modulation in absence epileptic rats. Thus, explanation of LPS evoked small differences in the time course of LPS evoked effects on SWD number and body temperature among the three rat strains is not straightforward. However, it was demonstrated that the LPS evoked increase in pro-inflammatory cytokines can increase absence epileptic activity between 30 and 270 min after injection independently from inflammation induced body temperature changes (Kovács et al., 2006, 2011), in which IL-1 $\beta$ may be one of the main pro-epileptic (pro-absence) mediators possibly via GABAergic neurotransmission (Van Luijtelaar et al., 2012) in WAG/Rij animals. Nevertheless, the presence of reactive astrocytes in the GAERS cortex and thalamus before the onset of absence epileptic seizures (Dutuit et al., 2000) and IL-1 $\beta$ induction in reactive astrocytes of adult GAERS rat somatosensory cortex at the onset of SWDs and the contribution of IL-1 $\beta$ to SWD occurrence were also demonstrated in GAERS rats (Akin et al., 2011). Thus, we can conclude that pro-inflammatory cytokines may have aggravating influence on absence epileptic activity (genesis and recurrence of SWDs) at least in the investigated two rat models (WAG/Rij, GAERS) of absence epilepsy and also in Long Evans rats.

It was demonstrated that (i) LPS and pro-inflammatory cytokines can induce the expression of COX-2 mRNA (Cao et al., 1995; Vezzani and Granata, 2005), (ii) prostaglandins may have a role in the seizure threshold decreasing effect of LPS (Sayyah et al., 2003), (iii) PGE $_{2}$ has proconvulsant effect (Sayyah et al., 2003) and (iv) the T-type $\mathrm{Ca}^{2+}$ channel evoked $\mathrm{Ca}^{2+}$ current (which has a role in the genesis of absence seizure) decreasing effect of IND may diminish absence epileptic activity in WAG/Rij rats, GAERS rats and Long Evans rats (Depaulis and Van Luijtelaar, 2005; Polack and Charpier, 2006; Shin, 2006; Van Luijtelaar et al., 2000). Thus, indomethacin may exert its effect on absence epileptic activity (e.g. SWD number decreasing effect injected alone and SWD number abolishing influence injected before LPS) via inhibition of both T-type $\mathrm{Ca}^{2+}$ channel and COX-2 (Kovács et al., 2006, 2011) in the three animal strains investigated.

In conclusion, we have demonstrated that i.p. LPS and its combination with i.p. IND changed the number and duration of SWDs and body temperature in WAG/Rij rats, GAERS rats and also in Long Evans rats suggesting that the same neuroinflammatory processes are in the background. In addition, the results of this study also suggest that Long Evans rat strain could be an animal model of human absence epilepsy as the experimental results obtained in these rats are similar to the experimental results obtained in the wellknown animal models (WAG/Rij and GAERS) of human absence epilepsy. These results extend our previous data suggesting that our methods based on LPS injection into freely moving absence epileptic rats are broadly applicable across rat models of absence epilepsy (such as WAG/Rij rats and GAERS rats) and Long Evans rats, to investigate the links between the activation of the inflammatory/cytokine system, the excitability of neuronal networks and the absence epileptic activity as well as the beneficial and adverse effects of new anti-inflammatory/anti-epileptic drugs, such as TLR4 antagonists (Maroso et al., 2010).

\section{Acknowledgements}

This work was supported by the National Development Agency of Hungary (under Grant no. TIOP-1.3.1.-07/2-2F-2009-2008) (Zsolt Kovács), TÁMOP 4.2.1./B-09/1/KMR-2010-0003 (Gábor Juhász and Katalin Adrienna Kékesi) and the OTKA K100319 and K112565 Research Grants, the NAP B Program, as well as the Bolyai János Fellowship Grant of the Hungarian Academy of Sciences (Ârpád Dobolyi). We wish to thank Tamás Török (NYME SEK) for technical assistance.

\section{References}

Akin, D., Ravizza, T., Maroso, M., Carcak, N., Eryigit, T., Vanzulli, I., Aker, R.G., Vezzani A., Onat, F.Y., 2011. IL-1 $\beta$ is induced in reactive astrocytes in the somatosensory cortex of rats with genetic absence epilepsy at the onset of spike-and-wave discharges, and contributes to their occurrence. Neurobiol. Dis. 44, 259-269.

Akman, O., Demiralp, T., Ates, N., Onat, F.Y., 2010. Electroencephalographic differences between WAG/Rij and GAERS rat models of absence epilepsy. Epilepsy Res. 89, 185-193.

Bazyan, A.S., Van Luijtelaar, G., 2013. Neurochemical and behavioral features in genetic absence epilepsy and in acutely induced absence seizures. ISRN Neurol. 2013, 875834, http://dx.doi.org/10.1155/2013/875834.

Birioukova, L.M., Midzyanovskaya, I.S., Lensu, S., Tuomisto, L., Van Luijtelaar, G., 2005 Distribution of D1-like and D2-like dopamine receptors in the brain of genetic epileptic WAG/Rij rats. Epilepsy Res. 63, 89-96. 
Broicher, T., Kanyshkova, T., Meuth, P., Pape, H.C., Budde, T., 2008. Correlation of T-channel coding gene expression, IT, and the low threshold Ca2+ spike in the thalamus of a rat model of absence epilepsy. Mol. Cell. Neurosci. 39, 384-399.

Budde, T., Caputi, L., Kanyshkova, T., Staak, R., Abrahamczik, C., Munsch, T., Pape, H.C., 2005. Impaired regulation of thalamic pacemaker channels through an imbalance of subunit expression in absence epilepsy. J. Neurosci. 25, 9871-9882.

Cao, C., Matsumura, K., Yamagata, K., Watanabe, Y., 1995. Induction by lipopolysaccharide of cyclooxygenase-2 mRNA in rat brain; its possible role in the febrile response. Brain Res. 697, 187-196.

Chen, S.D., Yeh, K.H., Huang, Y.H., Shaw, F.Z., 2011. Effect of intracranial administration of ethosuximide in rats with spontaneous or pentylenetetrazol-induced spike-wave discharges. Epilepsia 52, 1311-1318.

Coenen, A.M., Van Luijtelaar, E.L., 2003. Genetic animal models for absence epilepsy: a review of the WAG/Rij strain of rats. Behav. Genet. 33, 635-655.

Depaulis, A., Van Luijtelaar, G., 2005. Genetic models of absence epilepsy in the rat In: Pitkänen, A., Schwartzkroin, P.A., Moshé, S.L. (Eds.), Models of Seizures and Epilepsy. Academic Press, pp. 233-248 (Chapter 18).

Dogan, M.D., Ataoglu, H., Akarsu, E.S., 2002. Characterization of the hypothermic component of LPS-induced dual thermoregulatory response in rats. Pharmacol. Biochem. Behav. 72, 143-150.

Dutuit, M., Didier-Bazès, M., Vergnes, M., Mutin, M., Conjard, A., Akaoka, H., Belin, M.F., Touret, M., 2000. Specific alteration in the expression of glial fibrillary acidic protein, glutamate dehydrogenase, and glutamine synthetase in rats with genetic absence epilepsy. Glia 32, 15-24.

Eriksson, C., Nobel, S., Winblad, B., Schultzberg, M., 2000. Expression of interleukin 1 alpha and beta, and interleukin 1 receptor antagonist mRNA in the rat central nervous system after peripheral administration of lipopolysaccharides. Cytokine 12, 423-431.

Galic, M.A., Riazi, K., Heida, J.G., Mouihate, A., Fournier, N.M., Spencer, S.J., Kalynchuk, L.E., Teskey, G.C., Pittman, Q.J., 2008. Postnatal inflammation increases seizure susceptibility in adult rats. J. Neurosci. 28, 6904-6913.

Goralski, K.B., Abdulla, D., Sinal, C.J., Arsenault, A., Renton, K.W., 2005. Toll-like receptor-4 regulation of hepatic Cyp3a11 metabolism in a mouse model of LPS-induced CNS inflammation. Am. J. Physiol. Gastrointest. Liver Physiol. 289, 434-443.

Györffy, B., Kovács, Z., Gulyássy, P., Simor, A., Völgyi, K., Orbán, G., Baracskay, P. Szabó, Z., Janáky, T., Dobolyi, A., Juhász, G., Czurkó, A., Kékesi, K.A., 2014. Brain protein expression changes in WAG/Rij rats, a genetic rat model of absence epilepsy after peripheral lipopolysaccharide treatment. Brain Behav. Immun. $35,86-95$.

Hashimoto, M., Bando, T., Iriki, M., Hashimoto, K., 1998. Effect of indomethacin on febrile response to recombinant human interleukin 1-alpha in rabbits. Am. J. Physiol. 255, 527-533.

Huang, K.F., Huang, W.T., Lin, K.C., Lin, M.T., Chang, C.P., 2010. Interleukin-1 receptor antagonist inhibits the release of glutamate, hydroxyl radicals, and prostaglandin $\mathrm{E}(2)$ in the hypothalamus during pyrogen-induced fever in rabbits. Eur. J. Pharmacol. 629, 125-131

Huang, H.Y., Lee, H.W., Chen, S.D., Shaw, F.Z., 2012. Lamotrigine ameliorates seizures and psychiatric comorbidity in a rat model of spontaneous absence epilepsy. Epilepsia 53, 2005-2014

Jones, N.C., Martin, S., Megatia, I., Hakami, T., Salzberg, M.R., Pinault, D., Morris, M.J. O'Brien, T.J., Van den Buuse, M., 2010. A genetic epilepsy rat model displays endophenotypes of psychosis. Neurobiol. Dis. 39, 116-125.

Kennard, J.T., Barmanray, R., Sampurno, S., Ozturk, E., Reid, C.A., Paradiso, L., D’Abaco, G.M., Kaye, A.H., Foote, S.J., O’Brien, T.J., Powell, K.L., 2011. Stargazin and AMPA receptor membrane expression is increased in the somatosensory cortex of Genetic Absence Epilepsy Rats from Strasbourg. Neurobiol. Dis. 42, 48-54.

Klein, J.P., Khera, D.S., Nersesyan, H., Kimchi, E.Y., Waxman, S.G., Blumenfeld, H., 2004. Dysregulation of sodium channel expression in cortical neurons in a rodent model of absence epilepsy. Brain Res. 1000, 102-109.

Kovács, Z., Czurkó, A., Kékesi, K.A., Juhász, G., 2011. Intracerebroventricularly administered lipopolysaccharide enhances spike-wave discharges in freely moving WAG/Rij rats. Brain Res. Bull. 85, 410-416.

Kovács, Z., Czurkó, A., Kékesi, K.A., Juhász, G., 2012. Neonatal tricyclic antidepressant clomipramine treatment reduces the spike-wave discharge activity of the adult WAG/Rij rat. Brain Res. Bull. 89, 102-107.

Kovács, Z., Kekesi, K.A., Juhasz, G., Dobolyi, A., 2014. The antiepileptic potential of nucleosides. Curr. Med. Chem. 21, 788-821.

Kovács, Z., Kékesi, K.A., Szilágyi, N., Abrahám, I., Székács, D., Király, N., Papp, E. Császár, I., Szego, E., Barabás, K., Péterfy, H., Erdei, A., Bártfai, T., Juhász, G., 2006. Facilitation of spike-wave discharge activity by lipopolysaccharides in Wistar Albino Glaxo/Rijswijk rats. Neuroscience 140, 731-742.

Kovács, Z., Slézia, A., Bali, Z.K., Kovács, P., Dobolyi, A., Szikra, T., Hernádi, I., Juhász, G. 2013. Uridine modulates neuronal activity and inhibits spike-wave discharges of absence epileptic Long Evans and Wistar Albino Glaxo/Rijswijk rats. Brain Res. Bull. 97, 16-23.

Kuisle, M., Wanaverbecq, N., Brewster, A.L., Frère, S.G., Pinault, D., Baram, T.Z., Lüthi, A., 2006. Functional stabilization of weakened thalamic pacemaker channel regulation in rat absence epilepsy. J. Physiol. 575 (Pt 1), 83-100.

Li, H., Kraus, A., Wu, J., Huguenard, J.R., Fisher, R.S., 2006. Selective changes in thalamic and cortical GABAA receptor subunits in a model of acquired absence epilepsy in the rat. Neuropharmacology 51, 121-128.

Liu, X.B., Coble, J., Van Luijtelaar, G., Jones, E.G., 2007. Reticular nucleus-specific changes in alpha3 subunit protein at GABA synapses in genetically epilepsyprone rats. Proc. Natl. Acad. Sci. U.S.A. 104, 12512-12517.
Maroso, M., Balosso, S., Ravizza, T. Liu, J., Aronica, E., Iyer, A.M., Rossetti, C., Molteni, M., Casalgrandi, M., Manfredi, A.A., Bianchi, M.E., Vezzani, A., 2010. Toll-like receptor 4 and high-mobility group box-1 are involved in ictogenesis and can be targeted to reduce seizures. Nat. Med. 16, 413-419.

Meeren, H.K., Pijn, J.P., Van Luijtelaar, E.L., Coenen, A.M., Lopes da Silva, F.H., 2002 Cortical focus drives widespread corticothalamic networks during spontaneous absence seizures in rats. J. Neurosci. 22, 1480-1495.

Merlo, D., Mollinari, C., Inaba, Y., Cardinale, A., Rinaldi, A.M., D’Antuono, M., D’Arcangelo, G., Tancredi, V., Ragsdale, D., Avoli, M., 2007. Reduced GABAB receptor subunit expression and paired-pulse depression in a genetic mode of absence seizures. Neurobiol. Dis. 25, 631-641.

Mlodzikowska-Albrecht, J., Steinborn, B., Zarowski, M., 2007. Cytokines, epilepsy and epileptic drugs-is there a mutual influence? Pharmacol. Rep. 59, 129-138.

Ngomba, R.T., Biagioni, F., Casciato, S., Willems-van Bree, E., Battaglia, G., Bruno, V., Nicoletti, F., Van Luijtelaar, E.L., 2005. The preferential mGlu2/3 receptor antagonist, LY341495, reduces the frequency of spike-wave discharges in the WAG/Rij rat model of absence epilepsy. Neuropharmacology 49, 89-103.

Ngomba, R.T., Santolini, I., Biagioni, F., Molinaro, G., Simonyi, A., Van Rijn, C.M. D’Amore, V., Mastroiacovo, F., Olivieri, G., Gradini, R., Ferraguti, F., Battaglia, G., Bruno, V., Puliti, A., Van Luijtelaar, G., Nicoletti, F., 2011. Protective role for type1 metabotropic glutamate receptors against spike and wave discharges in the WAG/Rij rat model of absence epilepsy. Neuropharmacology 60, 1281-1291.

Paxinos, G., Watson, C., 2005. The Rat Brain in Stereotaxic Coordinates. Academic Press, San Diego.

Polack, P.O., Charpier, S., 2006. Intracellular activity of cortical and thalamic neurones during high-voltage rhythmic spike discharge in Long-Evans rats in vivo. J. Physiol. 571 (Pt 2), 461-476.

Powell, K.L., Cain, S.M., Ng, C., Sirdesai, S., David, L.S., Kyi, M., Garcia, E., Tyson, J.R. Reid, C.A., Bahlo, M., Foote, S.J., Snutch, T.P., O’Brien, T.J., 2009. A Cav3.2 T-type calcium channel point mutation has splice-variant-specific effects on function and segregates with seizure expression in a polygenic rat model of absence epilepsy. J. Neurosci. 29, 371-380.

Princivalle, A.P., Richards, D.A., Duncan, J.S., Spreafico, R., Bowery, N.G., 2003. Modification of $\mathrm{GABA}(\mathrm{B} 1)$ and $\mathrm{GABA}(\mathrm{B} 2)$ receptor subunits in the somatosensory cerebral cortex and thalamus of rats with absence seizures (GAERS). Epilepsy Res. 55, 39-51.

Riazi, K., Galic, M.A., Pittman, Q.J., 2010. Contributions of peripheral inflammation to seizure susceptibility: cytokines and brain excitability. Epilepsy Res. 89, 34-42.

Rivest, S., 2003. Molecular insights on the cerebral innate immune system. Brain Behav. Immun. 17, 13-19.

Rodgers, K.M., Hutchinson, M.R., Northcutt, A., Maier, S.F., Watkins, L.R., Barth, D.S. 2009. The cortical innate immune response increases local neuronal excitability leading to seizures. Brain 132, 2478-2486.

Sayyah, M., Javad-Pour, M., Ghazi-Khansari, M., 2003. The bacterial endotoxin lipopolysaccharide enhances seizure susceptibility in mice: involvement of proinflammatory factors: nitric oxide and prostaglandins. Neuroscience 122 , $1073-1080$

Shaw, F.Z., 2004. Is spontaneous high-voltage rhythmic spike discharge in Long Evans rats an absence-like seizure activity? J. Neurophysiol. 91, 63-77.

Shaw, F.Z., 2007. 7-12 Hz high-voltage rhythmic spike discharges in rats evaluated by antiepileptic drugs and flicker stimulation. J. Neurophysiol. 97, 238-247.

Shaw, F.Z., Chuang, S.H., Shieh, K.R., Wang, Y.J., 2009. Depression- and anxiety-like behaviors of a rat model with absence epileptic discharges. Neuroscience 160 382-393.

Shin, H.S., 2006. T-type Ca2+ channels and absence epilepsy. Cell Calcium 40 191-196.

Snead, O.C., 1995. Basic mechanisms of generalized absence seizures. Ann. Neurol. 37, 146-157.

Spreafico, R., Mennini, T., Danober, L., Cagnotto, A., Regondi, M.C., Miari, A., De Blas A. Vergnes, M., Avanzini, G., 1993. GABAA receptor impairment in the genetic absence epilepsy rats from Strasbourg (GAERS): an immunocytochemical and receptor binding autoradiographic study. Epilepsy Res. 15, 229-238.

Strauss, U., Kole, M.H., Bräuer, A.U., Pahnke, J., Bajorat, R., Rolfs, A., Nitsch, R., Deisz R.A., 2004. An impaired neocortical Ih is associated with enhanced excitability and absence epilepsy. Eur. J. Neurosci. 19, 3048-3058.

Turrin, N.P., Gayle, D., Ilyin, S.E., Flynn, M.C., Langhans, W., Schwartz, G.J., PlataSalamán, C.R., 2001. Pro-inflammatory and anti-inflammatory cytokine mRNA induction in the periphery and brain following intraperitoneal administration of bacterial lipopolysaccharide. Brain Res. Bull. 54, 443-453.

Van de Bovenkamp-Janssen, M.C., Van der Kloet, J.C., Van Luijtelaar, G., Roubos, E.W. 2006. NMDA-NR1 and AMPA-GluR4 receptor subunit immunoreactivities in the absence epileptic WAG/Rij rat. Epilepsy Res. 69, 119-128.

Van Luijtelaar, G., Lyashenko, S., Vastyanov, R., Verbeek, G., Oleinik, A., Van Rijn C., Volokhova, G., Shandra, A., Coenen, A., Godlevsky, L., 2012. Cytokines and absence seizures in a genetic rat model. Neurophysiology 43, 478-486

Van Luijtelaar, G., Sitnikova, E., Littjohann, A., 2011. On the origin and suddenness of absences in genetic absence models. Clin. EEG Neurosci. 42, 83-97.

Van Luijtelaar, G., Wiaderna, D., Elants, C., Scheenen, W., 2000. Opposite effects of $\mathrm{T}$ - and L-type $\mathrm{Ca}(2+)$ channels blockers in generalized absence epilepsy. Eur. J. Pharmacol. 406, 381-389.

Vezzani, A., Aronica, E., Mazarati, A., Pittman, Q.J., 2013. Epilepsy and brain inflammation. Exp. Neurol. 244, 11-21.

Vezzani, A., Balosso, S., Ravizza, T., 2008. The role of cytokines in the pathophysiology of epilepsy. Brain Behav. Immun. 22, 797-803.

Vezzani, A., Granata, T., 2005. Brain inflammation in epilepsy: experimental and clinical evidence. Epilepsia 46, 1724-1743 
Vezzani, A., Maroso, M., Balosso, S., Sanchez, M.A., Bartfai, T., 2011. IL-1 receptor/Tolllike receptor signaling in infection, inflammation, stress and neurodegeneration couples hyperexcitability and seizures. Brain Behav. Immun. 25, 1281-1289.

Wang, X., Barone, F.C., Aiyar, N.V., Feuerstein, G.Z., 1997. Interleukin-1 receptor and receptor antagonist gene expression after focal stroke in rats. Stroke 28, 155-162.
Wang, Y.S., White, T.D., 1999. The bacterial endotoxin lipopolysaccharide causes rapid inappropriate excitation in rat cortex. J. Neurochem. 72 $652-660$.

Yabuuchi, K., Minami, M., Katsumata, S., Satoh, M., 1994. Localization of type interleukin-1 receptor mRNA in the rat brain. Brain Res. Mol. Brain Res. 27, 27-36. 